\title{
PARASIT PADA IKAN KERAPU DI PANTI BENIH DAN UPAYA PENANGGULANGANNYA
}

\author{
Zafran"), Isti Koesharyani *) dan Kei Yuasa**)
}

\begin{abstract}
ABSTRAK
Penelitian perbenihan kerapu sudah mulai dilakukan di Lolitkanta Gondol sejak tiga tahun yang lalu. Namun demikian masih ditemukan banyak permasalahan terutama kematian induk selama pemeliharaan di panti benih. Suatu penelitian untuk mengetahui jenis parasit yang menyerang induk kerapu telah dilakukan di Lolitkanta Gondol, Bali. Sampel parasit diidentifikasi melalui pengamatan langsung secara mikroskopis terhadap preparat segar dari insang serta parasit yang diperoleh melalui perendaman induk dalam air tawar. Hasil pengamatan menunjukkan bahwa parasit yang menyerang ikan kerapu antara lain Benedenia, Neobenedenia, Diplectanum, Pseudorhabdosynochus, Haliotrema, Trichodina, Cryptocaryon irritans dan Lepeophtheirus. Parasit yang terlihat mempunyai dampak paling serius terhadap kerapu tikus (Cromileptes altivelis) adalah cacing insang (Diplectanum, Pseudorhabdosynochus, Haliotrema) dan C. irritans. Perlakuan dengan formalin pada konsentrasi $125 \mathrm{mg} / \mathrm{L}$ selama satu jam atau 30 $\mathrm{mg} / \mathrm{L}$ selama $24 \mathrm{jam}$, atau perlakuan dengan air laut dengan salinitas $60 \mathrm{ppt}$ selama 15 menit terbukti efektif mematikan cacing insang tanpa efek negatif terhadap ikan. C. irritans dapat diatasi dengan ion tembaga dengan konsentrasi 0,03-0,07 mg/L selama seminggu.
\end{abstract}

ABSTRACT: Parasites on grouper in hatchery and its control methods. By: Zafran, Isti Koesharyani and Kei Yuasa.

Breeding of groupers have been conducted at Gondol Research Station for Coastal Fisheries for three years, but some problems still occur, especially mortality of spawners after being reared for several months in hatchery. An experiment to identify some parasites that commonly infest on groupers has been conducted. Parasites were identified microscopically. Results showed that common parasites infest on groupers were Benedenia, Neobenedenia, Pseudorhabdosynochus, Haliotrema, Diplectanum, Trichodina, Cryptocaryon irritans and Lepeophtheirus. The most serious threat for grouper (Cromileptes altivelis) are gill flukes (Diplectanum, Pseudorhabdosynochus. Haliotrema) and C. irritans. Treatment with formalin at concentration of $125 \mathrm{mg} / \mathrm{L}$ for $1 \mathrm{~h}$ or $30 \mathrm{mg} / \mathrm{L}$ for $24 \mathrm{~h}$, or treatment with sea water at $60 \mathrm{ppt}$ for $15 \mathrm{~min}$ proved to be effective against gill flukes without any side effect in the treated fish. C. irritans infection was removed by the treatment with 0.03-0.07 mg/L ionized copper in one week.

KEYWORDS: groupers, parasites, control.

\section{PENDAHULUAN}

Ikan kerapu merupakan ikan bernilai ekonomis tinggi di Indonesia mengingat rasanya yang enak dan harganya yang mahal di luar negeri. Selama ini kebutuhan akan ikan kerapu ukuran konsumsi diperoleh dari penangkapan di alam, yaitu di perairan karang. Dalam penangkapan ikan kerapu, banyak nelayan menggunakan bahan peledak atau racun potasium sianida (KCN). Dampak negatifnya adalah rusaknya terumbu karang yang merupakan habitat ikan kerapu dan ikan-ikan karang lainnya yang pada akhirnya dapat menyebabkan kepunahan ikanikan tersebut.

Upaya perbenihan kerapu macan (Epinephelus fuscoguttatus) telah berhasil dilakukan di Sub Balai Penelitian Perikanan Budidaya Pantai Serang, Jawa Barat (Mayunar et al., 1991) dan pada tahun 1995 di Loka Penelitian Perikanan Pantai Gondol juga telah berhasil dipijahkan satu jenis kerapu yang harganya cukup mahal yakni

\footnotetext{
*) Peneliti pada Loka Penelitian Perikanan Pantai Gondol - Bali

*) JICA Expert (ATA-379) Lolitkanta Gondol - Bali
} 
kerapu tikus, C. altivelis (Aslianti, 1996). Diharapkan dalam waktu yang tidak terlalu lama sudah berhasil dirakit teknologi perbenihan kerapu tikus sehingga nantinya kebutuhan akan kerapu tikus ukuran kosumsi dapat dipenuhi dari hasil budidaya.

Kematian kerapu sering dijumpai dalam keramba jaring apung, khususnya di Pulau Bungin (Sumbawa Besar, NTB). Sedangkan pada panti benih, kematian induk merupakan kendala yang sering dihadapi dalam wadah pemeliharaan kerapu. Pada ikan yang mati biasanya banyak ditemukan parasit, baik pada insang, kulit, maupun mata. Induk ikan yang dipelihara di panti benih dengan kondisi kepadatan tinggi dan pergantian air yang terbatas menyebabkan ikan stres sehingga daya tahannya terhadap serangan parasit dan penyakit jadi menurun. Kondisi panti benih yang demikian memungkinkan organisme parasit dan penyakit dapat berkembang biak dengan cepat sehingga dapat merugikan inang bahkan dapat menyebabkan kematian.

Informasi tentang perbenihan, nutrisi, penyakit, dan sifat-sifat biologi ikan kerapu masih sangat langka. Penelitian ini dilakukan dengan tujuan untuk mengetahui jenis-jenis parasit yang menyerang ikan kerapu di panti benih Lolitkanta Gondol, Bali. Dengan mengetahui jenis-jenis parasit tersebut diharapkan dapat ditentukan metode pencegahan dan penanggulangannya sehingga salah satu kendala dalam pemeliharaan ikan kerapu dapat diatasi.

\section{BAHAN DAN METODE}

\section{Ikan Kerapu}

Ikan kerapu diperoleh dari panti benih di Gondol dan dari tempat penampungan para pengumpul yang terdapat di sekitar Gondol, baik ikan yang sehat maupun ikan yang baru mati.

\section{Identifikasi Parasit}

Contoh parasit diperoleh dengan cara merendam ikan kerapu dalam air tawar selama 30 menit sampai parasit yang menempel pada ikan terlepas. Parasit yang terlepas selanjutnya dikumpulkan dalam botol, sebagian diamati dan diidentifikasi secara langsung melalui mikroskop berdasarkan Grabda (1991), Ogawa et al. (1995a, 1995b), Kearn (1992), Klassen (1993a; 1993b),
Kritsky \& Burton (1986), Vala et al. (1982) dan Whittington et al. (1994), sedang yang sebagian lagi diawetkan dalam formalin yang disangga (buffered formalin). Identifikasi parasit dilakukan secara mikroskopis terhadap preparat segar dan preparat yang sudah diwarnai dengan larutan ammonium-picric acid-glyserin (Ogawa, 1993).

\section{Pengendalian}

Uji efektivitas beberapa bahan kimia, yaitu formalin, hidrogen peroksida, kalium permanganat, tembaga sulfat dan natrium klorida telah dilakukan dalam upaya menemukan metode penanggulangan yang tepat dan aman terhadap ikan.

\section{a. Pengaruh bahan kimia terhadap parasit insang (in-vitro)}

Konsentrasi masing-masing bahan kimia yang digunakan adalah 125, 200 dan $250 \mathrm{mg} / \mathrm{L}$ untuk formalin; 0,$031 ; 0,063$ dan $0,125 \%$ untuk hidrogen peroksida; 1 , 2 dan $4 \mathrm{mg} / \mathrm{L}$ untuk tembaga sulfat dan kalium permanganat, dan 1, 2 dan $3 \%$ untuk natrium klorida. Beberapa filamen insang yang terinfeksi parasit dimasukkan ke dalam cawan petri yang sudah berisi bahan kimia uji dengan berbagai konsentrasi. Pengamatan secara mikroskopis dilakukan terhadap kematian parasit selama dua jam. Suhu selama pengamatan adalah $28^{\circ} \mathrm{C}$.

\section{b. Toksisitas formalin terhadap ikan}

Ikan yang digunakan adalah kerapu tikus ( $C$. altivelis) sehat sebanyak empat ekor untuk setiap perlakuan dengan bobot tubuh rata-rata $150 \mathrm{~g} /$ ekor. Konsentrasi formalin yang diujikan adalah $30 \mathrm{mg} / \mathrm{L}$ selama tujuh hari, $60 \mathrm{mg} / \mathrm{L}$ selama tiga hari, $125 \mathrm{mg} / \mathrm{L}$ selama dua jam, dan $250 \mathrm{mg} / \mathrm{L}$ selama satu jam.

\section{c. Pengaruh salinitas terhadap ikan}

Salinitas yang diujikan adalah 0 ppt selama 1,2, dan 12 jam, 10 ppt selama tujuh hari, dan 60 ppt selama 30 menit. Sedangkan ikan uji yang digunakan adalah $C$. altivelis sehat sebanyak empat ekor untuk setiap perlakuan dengan bobot rata-rata 150 g/ekor. 


\section{d. Uji aplikasi di bak pemeliharaan ikan}

Konsentrasi yang diujikan adalah formalin dengan konsentrasi 125 dan $250 \mathrm{mg} / \mathrm{L}$ selama satu jam, $30 \mathrm{mg} / \mathrm{L}$ selama dua hari serta $60 \mathrm{ppt}$ air laut selama 15 menit terhadap ikan yang terinfeksi Monogenea masing-masing empat ekor untuk setiap perlakuan. Sedangkan untuk Cryptocaryon dilakukan selama satu minggu menggunakan tembaga sulfat dengan konsentrasi berkisar 0,03-0,07 $\mathrm{mg} / \mathrm{L}$. Penggunaan ion tembaga adalah sebagai berikut: kantung saringan yang berisi lempengan ion tembaga digantungkan pada ujung pipa pemasukan air. Dengan cara ini maka air laut yang akan digunakan akan melewati kantung saringan tersebut sebelum masuk ke dalam bak pemeliharaan. Dengan mengatur jumlah lempengan ion tembaga dalam kantung saringan maka konsentrasi ion tembaga dalam air dapat diperhitung. kan antara 0,03-0,07 mg/L.

\section{HASIL DAN PEMBAHASAN}

\section{Jenis Parasit}

Parasit yang umum ditemukan menginfeksi ikan kerapu di Lolitkanta Gondol adalah dari klas Monogenea (monogenetic trematoda) antara lain Benedenia, Neobenedenia, Diplectanum, Pseuodorhabdosynochus dan Haliotrema. Dari Ciliata adalah Trichodina dan dari klas Copepoda adalah Lepeophtheirus dan Cryptocaryon irritans (Gambar 1, 2, 3, 4, 5, 6, 7, dan 8). Parasit-parasit tersebut terutama menyerang insang, mata dan kulit (Koesharyani et al., 1997). Dalam jumlah sedikit keberadaan parasit tidak akan merugikan ikan kerapu sebagai inang, tetapi apabila dalam jumlah banyak tentu akan menyebabkan ikan kekurangan darah atau luka dan pada akhirnya memberi peluang bagi terjadinya infeksi sekunder oleh bakteri patogen.

a. Benedenia (Ordo Dactylogyridea, Famili Capsalidae) mempunyai ciri spesifik, yaitu terdapatnya dua alat hisap besar (bowl-like sucker) di kepala (Gambar 1). Benedenia pernah dilaporkan menyerang Seriola di Jepang (Kubota \& Takakuwa dalam Grabda, 1991), kakap dan kerapu di Malaysia (Leong, 1994), Lutjanus carponotatus di Australia (Whittington et al., 1994) dan "Yellowtail", Seriola quinqueradiata (Kearn, 1992). Di
Gondol, Benedenia juga ditemukan menyerang ikan Napoleon (Cheilinus). Infeksi Benedenia dapat menyebabkan pertumbuhan terhambat, luka pada kulit dan infeksi sekunder oleh bakteri. Dari klas Monogenea, spesies dari Famili Capsalidae merupakan parasit yang paling berbahaya (Grabda, 1991). Satu spesies lain dari Famili Capsalidae, yakni Nitzschia sturionis dilaporkan mampu menghisap darah ikan sturgeon sebanyak $0,5 \mathrm{~cm}^{3}$ per hari (Dogiel \& Lutta dalam Grabda, 1991).

b. Neobenedenia (dari Ordo Dactylogyridea, Famili Capsalidae) dibedakan dari Benedenia berdasarkan tidak adanya vaginal opening pada Neobenedenia tetapi ada pada Benedenia (Gambar 2). Selain itu seminal receptacle pada Benedenia terpisah dari ovari sedang pada Neobenedenia bersatu (Ogawa et al., 1995a, 1995 b ). Dari pengamatan parasit pada ikan kerapu di Gondol, Neobenedenia lebih dominan dibanding Benedenia dan ukurannyapun terlihat lebih besar dibanding Benedenia. Neobenedenia girellae ditemukan di Jepang pertama kali pada tahun 1991 pada dua spesies ikan budidaya laut, yaitu pada Japanese flounder, Paralichthys olivaceus dan tiger puffer, Takifugu rubripes (Ogawa et al., 1995b). Parasit ini terutama ditemukan di daerah tropis (Bondad-Reantaso et al., 1995). Parasit ini sekarang termasuk patogen yang penting di Jepang sebab dapat mematikan ikan inang, tingkat spesifik inang yang rendah, tersebar luas, dan dapat masuk ke Jepang melalui impor liar ikan amberjack, Seriola dumerili (Ogawa et al., 1995a).

c. Diplectanum (dari Ordo Dactylogyridea, Famili Diplectanidae) mempunyai kekhasan yang membedakannya dari spesies lain dalam Ordo Dactylogyridea yaitu mempunyai squamodisc (satu di ventral dan satu di dorsal), dan sepasang jangkar yang terletak berjauhan (Gambar 3). Diplectanum dilaporkan menyerang ikan-ikan laut budidaya pada jaring apung di Singapura (Chong \& Chao, 1986) dan di Malaysia (Leong, 1994). Diplectanum adalah parasit yang hidup pada insang ikan. Ikan yang terinfeksi Diplectanum, sebagaimana infeksi oleh parasit-parasit insang lainnya, terlihat bernapas lebih cepat dengan tutup insang yang selalu terbuka. Chong \& Chao (1986) menyatakan bahwa infeksi Diplectanum mempunyai hubungan erat 
dengan penyakit sistemik seperti vibriosis. Insang yang diserang biasanya berwarna pucat dan produksi lendirnya berlebihan.

d. Pseudorhabdosynochus (dari Ordo Dactylogyridea, Famili Diplectanidae) mempunyai bentuk yang mirip sekali dengan Diplectanum (Gambar 4). Pseudorhabdosynochus dibedakan dari Diplectanum berdasarkan bentuk penisnya, Pseudorhabdosynochus mempunyai penis yang ujungnya berbentuk kait sedangkan Diplectanum lurus (Kritsky \& Burton, 1986).

e. Haliotrema (dari ordo Dactylogyridea, Famili Ancyrocephalidae) mempunyai bentuk mirip dengan Ancyrocephalus, yaitu cacing insang yang menyerang ikan-ikan air tawar (Gambar 5). Perbedaannya hanya terletak pada bentuk ususnya. Pada Ancyrocephalus ususnya bercabang dua sampai ujung sedangkan pada Haliotrema terlihat ujungnya saling menyatu. Haliotrema dilaporkan juga menginfeksi puffer fish, Takifugu niphobles (Klassen, 1993a) ostraciid fish (Vala et al., 1982; Klassen, 1993b), Lutjanus johni (Leong, 1994) dan Acantopagrus sp. (Byrnes, 1986).

f. Trichodina (dari Ordo Mobilia, Famili Trichodinidae) adalah parasit dengan ciri spesifik memiliki semacam cincin yang dipenuhi oleh bulu getar (Gambar 6). Trichodina terutama menyerang insang dan kulit, pada tingkat parah dapat menyebabkan iritasi jaringan luar insang. Infeksi Trichodina juga memberi peluang bagi bakteri patogen untuk menginfeksi ikan inang.

g. Lepeophtheirus (dari Ordo Copepoda, Famili Caligidae) mempunyai sefalotoraks yang lebar tapi tipis yang berfungsi sebagai jangkar untuk melekatkan tubuhnya pada inang (Gambar 7). Lepeophtheirus dibedakan dari Caligus karena tidak mempunyai dua jangkar yang disebut dengan lunulus dan empat pasang kaki renang. Lepeophtheirus memakan cairan jaringan tubuh ikan inang. Invasi Lepeophtheirus dalam jumlah banyak dapat menyebabkan inflamasi kulit inang. Hampir semua spesies dari Famili Caligidae adalah parasit pada ikan laut, hanya satu spesies yang dilaporkan pada ikan air tawar, yaitu Caligus lacustris (Grabda, 1991).

h. Cryptocaryon irritans (dari Ordo Heterostomata, Famili Ophryoglenidae) adalah parasit penyebah penyakit bercak putih pada ikan yang terserang (Gambar 8). Gejala yang ditimbulkan mirip dengan serangan Ichthyophthirius multifiliis pada ikan air tawar, tapi karena menyerang ikan laut maka sering juga disebut dengan Ichthyophthirius marinus. Bagian yang diserang biasanya adalah insang dan kulit, tapi sering juga ditemukan pada kornea mata sehingga dapat menyebabkan kebutaan. Invasi berat oleh parasit ini dapat menyebabkan kematian bagi ikan inang.

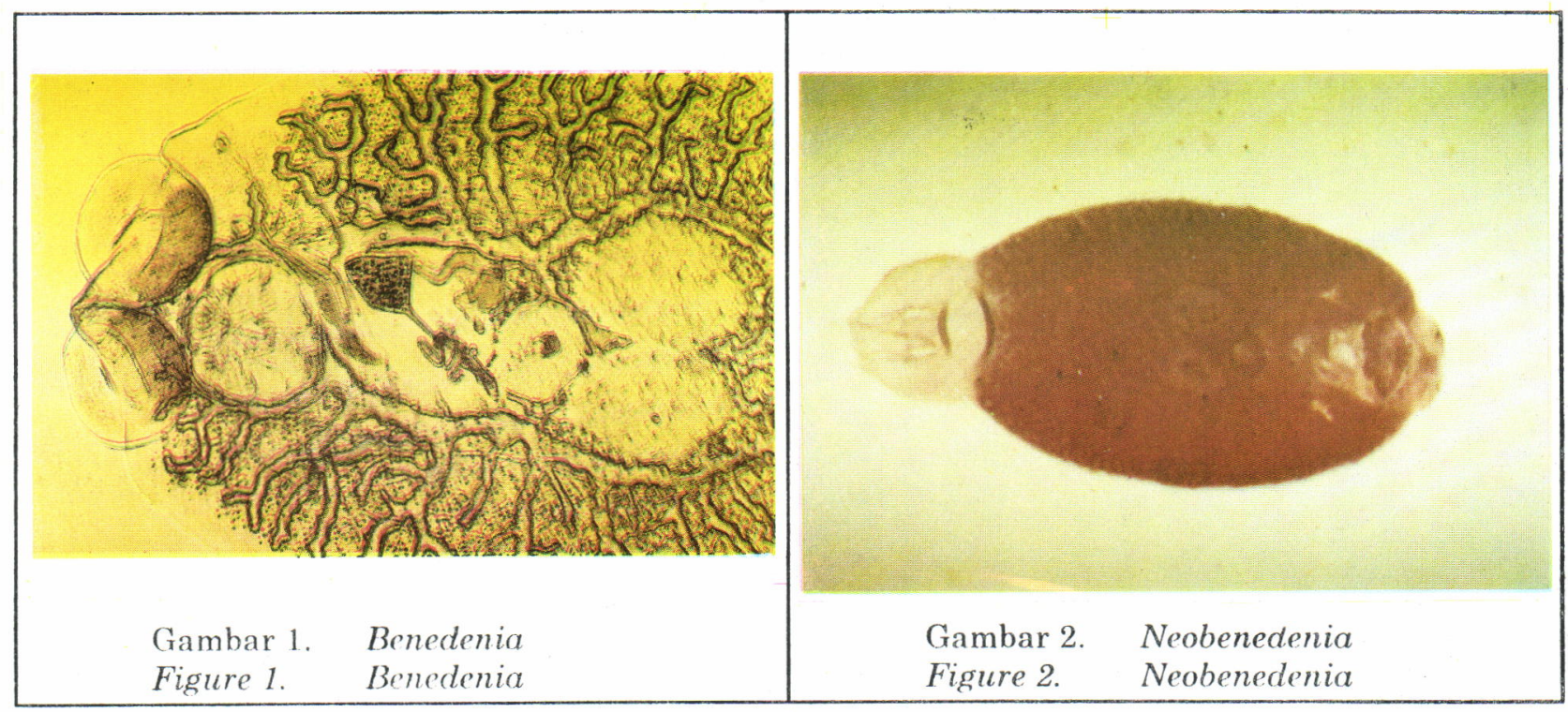



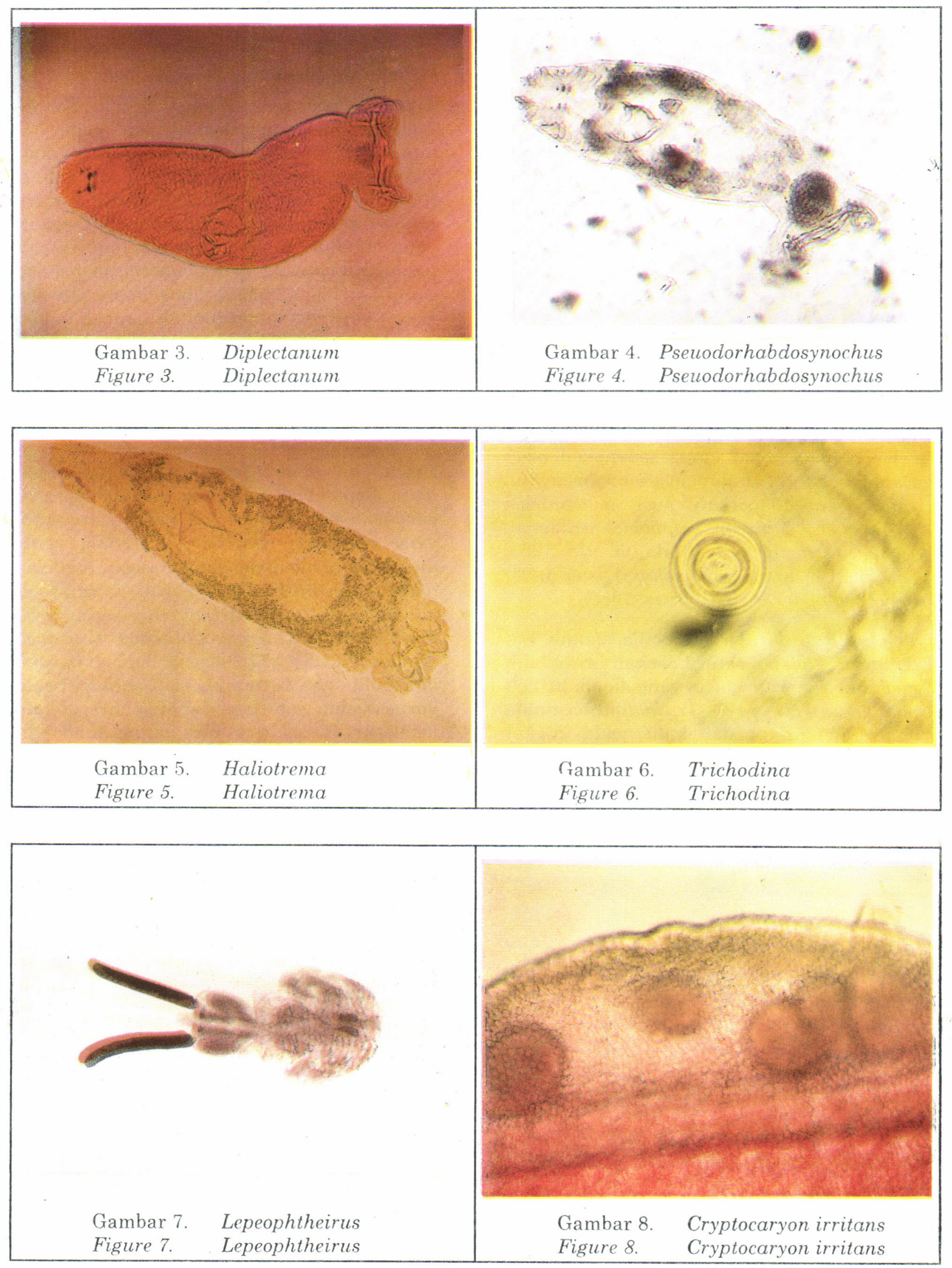
Dari semua parasit yang ditemukan tersebut ternyata yang berbahaya terhadap ikan kerapu terutama adalah parasit insang (Haliotrema, Diplectanum, Pseudorhabdosynochus). C. irritans, Benedenia dan Neobenedenia bila terdapat dalam jumlah banyak dan menyerang mata juga dapat menimbulkan kebutaan dan akhirnya kematian.

Siklus hidup parasit Monogenea (Benedenia, Neobenedenia, Diplectanum, Pseudorhabdosynochus, Haliotrema) adalah dengan menghasilkan telur yang dilengkapi dengan filamen panjang yang berfungsi untuk menempel pada substrat. Dalam waktu sekitar lima hari telur akan matang dan menetas menghasilkan onkomirasidia yang mempunyai bulu getar yang berfungsi aktif sebagai alat renang untuk mencari inang. Kalau sudah menemukan inang maka silia tersebut akan hilang dan onkomirasidium akan berkembang jadi dewasa.

Siklus hidup C.irritans disajikan pada Gambar 9. Trophont yang biasanya hidup di bawah epidermis ikan akan menghasilkan tomont yang dapat berenang bebas di dalam air sebelum men- jadi kista. Setelah masa inkubasi, kista akan berkembang dan menghasilkan theront yang dapat berenang bebas mencari inang. Dalam siklus hidup $C$. irritans, stadia yang sensitif terhadap bahan kimia adalah tomont dan theront.

\section{Penanggulangan Parasit}

Dari hasil uji pengaruh beberapa bahan kimia terhadap parasit insang ternyata hanya formalin dan perlakuan salinitas yang efektif, sedangkan hidrogen peroksida, kalium permanganat dan tembaga sulfat tidak efektif sama sekali. Hasil lengkap disajikan pada Tabel 1. Dari uji tingkat keamanannya terhadap ikan terlihat bahwa formalin pada konsentrasi $250 \mathrm{mg} / \mathrm{L}$ selama satu jam tidak mematikan ikan uji. Begitu juga sali. nitas 60 ppt selama 30 menit tetap aman bagi ikan kerapu. Pada salinitas 0 ppt selama satu jam ikan uji terlihat berenang normal tapi bila diperlakukan selama dua jam dapat menimbulkan stres, yang dicirikan dengan tingkah laku renang yang tidak normal. Hasil lengkap disajikan pada Tabel 2.

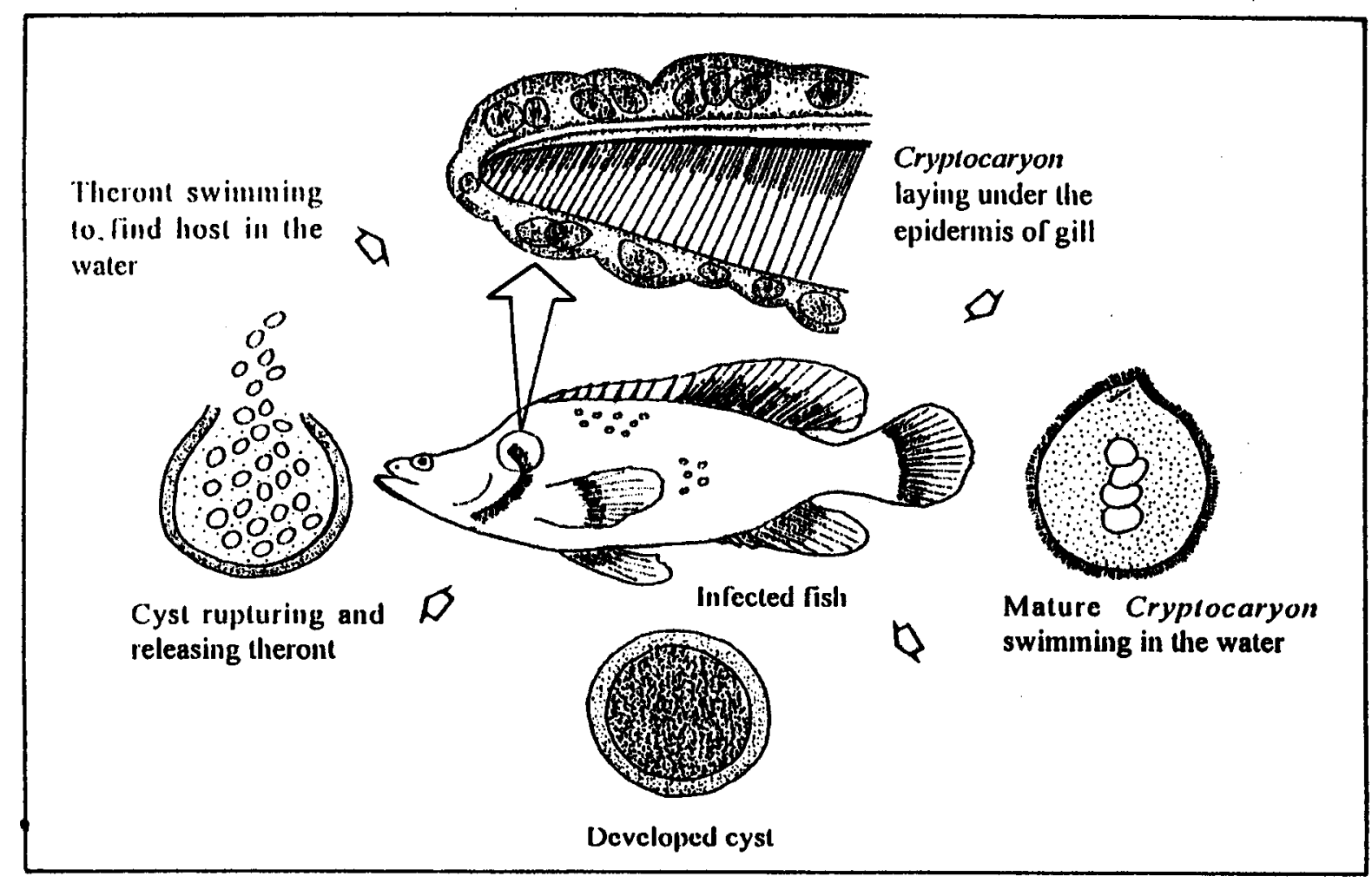

Gambar 9. Siklus hidup Cryptocaryon irritans (Urawa. 1995).

Figure 9. Life cycle of Cryptocaryon irritans (Urawa. 1995). 
Tabel 1. Pengaruh bahan kimia terhadap Monogenea yang terdapat dalam insang ikan kerapu Table 1. Effects of chemicals on survival of Monogenea infested the grouper gills*)

\begin{tabular}{lcc}
\hline \multicolumn{1}{c}{$\begin{array}{c}\text { Bahan kimia } \\
\text { Chemicals }\end{array}$} & $\begin{array}{c}\text { Konsentrasi } \\
\text { Concentration }\end{array}$ & $\begin{array}{c}\text { Waktu untuk kematian 100\% } \\
\text { Time of 100\% mortality }\end{array}$ \\
\hline Formalin & $250 \mathrm{mg} / \mathrm{L}$ & 34 menit (34 min.) \\
& $200 \mathrm{mg} / \mathrm{L}$ & 40 menit $(40$ min.) \\
Hidrogen peroksida (Hydrogen peroxide) & $125 \mathrm{mg} / \mathrm{L}$ & 60 menit (60 min.) \\
& $0.125 \%$ & 27 menit (27 min.) \\
Kalium permanganat (Potassium & $0.063 \%$ & tidak efektif (not effective) \\
permanganat) & $0.031 \%$ & tidak efektif (not effective) \\
& $4 \mathrm{mg} / \mathrm{L}$ & tidak efektif (not effective) \\
Tembaga sulfat (Copper sulfate) & $2 \mathrm{mg} / \mathrm{L}$ & tidak efektif (not effective) \\
& $1 \mathrm{mg} / \mathrm{L}$ & tidak efektif (not effective) \\
& $4 \mathrm{mg} / \mathrm{L}$ & tidak efektif (not effective) \\
& $2 \mathrm{mg} / \mathrm{L}$ & tidak efektif (not effective) \\
& $1 \mathrm{mg} / \mathrm{L}$ & tidak efektif (not effective) \\
Natrium klorida (Sodium chloride) & $3 \%$ & 5 menit (5 min.) \\
& $2 \%$ & 45 menit (45 min.) \\
& $1 \%$ & tidak efektif (not effective) \\
\hline
\end{tabular}

*) (Predominant species on the gills used in the experiment was Haliotrema)

Tabel 2. Pengaruh formalin dan salinitas terhadap sintasan ikan

Table 2. Effects of formalin and salinities on fish survival

\begin{tabular}{lcc}
\hline $\begin{array}{c}\text { Perlakuan } \\
\text { Treatment }\end{array}$ & $\begin{array}{c}\text { Konsentrasi dan lamanya uji/ } \\
\text { Concentration and exposure time }\end{array}$ & $\begin{array}{c}\text { Tanggapan ikan } \\
\text { Respons of fish }\end{array}$ \\
\hline Formalin & $30 \mathrm{ppm}, 7$ hari (days) & + \\
& $60 \mathrm{ppm}, 3$ hari (days) & + \\
$125 \mathrm{ppm}, 2$ jam (hours) & + \\
$250 \mathrm{ppm} \mathrm{1} \mathrm{jam} \mathrm{(hour)}$ & + \\
& $0 \mathrm{ppt}, 1$ jam (hour) & + \\
Salinitas (Salinity) & $0 \mathrm{ppt}, 2$ jam (hours) & + \\
& $0 \mathrm{ppt}, 12$ jam (hours) & + \\
& $10 \mathrm{ppt}, 7$ hari (days) & + \\
& $60 \mathrm{ppt}, 30$ menit (min) & + \\
\hline
\end{tabular}

+ : tidak ada dampak dan semua ikan hidup (no effect and all fish were alive)

\pm : ikan stres akibat bahan kimia, tetapi tetap hidup (fish was stressed by chemicals, but still alive)

: kemungkinan membunuh ikan (may kill fish) 


\section{Uji Aplikasi}

Dari uji aplikasi di bak pemeliharaan ikan terbukti bahwa parasit insang, kecuali C. irritans, dapat ditanggulangi secara sempurna dengan perlakuan formalin pada konsentrasi $250 \mathrm{mg} / \mathrm{L}$ selama satu jam. Tetapi perlakuan formalin 250 $\mathrm{mg} / \mathrm{L}$ dapat menimbulkan stres pada ikan apabila ikan tersebut juga terinfeksi oleh $C$. irritans. Karena itu metode yang dianjurkan adalah perlakuan dengan formalin pada konsentrasi 125 $\mathrm{mg} / \mathrm{L}$ selama satu jam, atau $30 \mathrm{mg} / \mathrm{L}$ selama 24 jam, atau air laut dengan salinitas $60 \mathrm{ppt}$ selama 15 menit. C. irritans dapat efektif ditanggulangi dengan penggunaan ion tembaga pada konsentrasi $0,03-0,07 \mathrm{mg} / \mathrm{L}$ selama satu minggu.

\section{KESIMPULAN}

1. Jenis parasit yang ditemukan pada ikan kerapu adalah Benedenia, Neobenedenia, Haliotrema, Diplectanum, Pseudorhabdosynochus, Trichodina, C. irritans, dan Lepeophtheirus.

2. Parasit yang paling berbahaya terhadap ikan kerapu adalah Haliotrema, Diplectanum, Pseudorhabdosynochus dan C. irritans.

3. Parasit insang dapat ditanggulangi dengan perendaman dalam larutan formalin $125 \mathrm{mg} / \mathrm{L}$, selama satu jam atau $30 \mathrm{mg} / \mathrm{L}$ selama 24 jam atau air laut dengan salinitas $60 \mathrm{ppt}$ selama 15 menit, sedang $C$. irritans dapat diatasi dengan ion tembaga pada konsentrasi 0,03 $0,07 \mathrm{mg} / \mathrm{L}$ selama seminggu.

\section{DAFTAR PUSTAKA}

Aslianti, T.1996. Pemeliharaan larva kerapu bebek Cromileptes altivelis dengan padat tebar berbeda. Jurnal Penelitian Perikanan Indonesia, 2 (2):6-12.

Bondad-Reantaso, M.G., K. Ogawa, M. Fukudome, and H. Wakabayashi. 1995. Reproduction and growth of Neobenedenia girellae (Monogenea: Capsalidae), a skin parasite of cultured marine fishes of Japan. Fish Pathology, 30(3): 227-231.

Byrnes, T. 1986. Five species of monogenea from Australian bream, Aranthopagrus spp. Aust. J. Zool. 34(1): 65-86.

Chong, Y.C. and T.M. Chao. 1986. Common diseases of marine foodfish. Fisheries Handbook No. 2, Primary Production Department, Ministry of National Development, Republic of Singapore. $33 \mathrm{p}$.

Grabda, J. 1991. Marine fish parasitology. Polish Scientific Publisher, Warsawa. 306 p.
Kearn, G.C. 1992. Mating in the capsalid monogenean Benedenia seriolae, a skin parasite of the yellowtail, Seriola quinqueradiata, in Japan. Publ. Seto Mar. Biol. Lab., 35(4/5):273-280.

Klassen, G.J. 1993a. A new species of Haliotrema (Monogenea: Ancyrocephalidae) from a Japanese puffer fish Takifugu niphobles (Tetraodontiformes: Tetraodontidae). International Journal for Parasitology, 23(6): 777-783.

Klassen, G.J. 1993b. Haliotrema species (Monogenea: Ancyrocephalidae) from Indo-Pacific box fishes (Tetraodontiformes: Ostraciidae). Can. J. Zool., 71: 2099-2110.

Koesharyani, I., K. Yuasa and Zafran. 1997. Control of parasitic in Cromileptes altivelis broodstock. Simp. Perik. Indonesia II, Ujung Pandang (in press).

Kritsky, D.C and M.B. Burton. 1986. The status of Pseudorhabdosynochus Yamaguti, 1958, and Cycloplectanum Oliver, 1968 (Monogenea: Diplecta. nidae). Proc. Biol. Soc. Wash. 99(1):17-20.

Leong, T.S. 1994. Parasites and diseases of cultured marine finfishes in South East Asia. School of Biological Science, University Sains Malaysia. $25 \mathrm{p}$.

Mayunar, P.T. Imanto, S. Diani, dan T. Yokokawa. 1991. Pemijahan ikan kerapu macan, Epinephelus fuscoguttatus. Bull. Pen. Perikanan, Edisi khusus 2: 15-22.

Ogawa, K. 1993. Fundamental manual for fish disease diagnosis. In Japan Fisheries Resource Conservation. Wakabayashi Hisatsuyu (od.) (in Japanese). p. 69.77.

Ogawa, K., M.G. Bondad-Reantaso, M. Fukudome, and H. Wakabayashi. 1995a. Neobenedenia girellae (Hargis, 1955) Yamaguti, 1963 (Monogenea: Capsalidae) from cultured marine fishes of Japan. J. Parasitol. 81(2): 223-227.

Ogawa, K., M.G. Bondad-Reantaso, and H. Wakabayashi. 1995b. Redescription of Benedenia epinepheli (Yamaguti, 1937) Meserve, 1938 (Monogenea: Capsalidae) from cultured and aquarium marine fishes of Japan. Canadian Journal of Fisheries and Aquatic Sciences. 52(1):62--70.

Vala, J. C., C. Maillard, and R.M. Overstreet. 1982. Haliotrema (monogenea: Ancyrocephalidae) from Ostraciid fishes in Guadeloupe, West Indies. J. Parasitol., 68(6): 1130-1137.

Whittington, I.D., G.C. Kearn, and M. BeverleyBurton. 1994. Benedenia rohdei $n$ sp. (monogenean: Capsalidae) from the gills of Lutjanus carponotatus (Perciformes: Lutjanidae) from the Great Barrier Reef. Queensland, Australia, with a description of the oncomiracidium. syst. Parasitol., 28(1): 5-13 